\title{
Crónica
}

\section{Mensaje de S.E. la Presidenta de la República con el que inicia un proyecto de ley que regula la despenalización de la interrupción voluntaria del embarazo en tres causales}

Disponible en: http://www.minsegpres.gob.cl/wp-content/upLoads/2015/01/1230-362despenalia-interrupcion-emabrazo-3-causales-con-ingreso-camara.pdf

El 31 de enero del 2015, la Presidenta de Chile Dra. Michelle Bachelet Jeria, en uso de sus facultades constitucionales, envió al Presidente de la Honorable Cámara de Diputados, el proyecto de ley sobre la despenalización de la interrupción voluntaria del embarazo en tres causales: 1. Para evitar un peligro para la vida de la mujer. 2. Cuando el embrión o feto padezca una alteración estructural congénita o genética incompatible con la vida extrauterina. 3. Cuando el embarazo es producto de una violación.

El Proyecto de Ley a texto completo está disponible en la página web del Ministerio Secretaría General de la Presidencia, para conocimiento de todos los ciudadanos del país, especialmente para los médicos y personal profesional y técnico, responsables del cuidado de la salud de la mujer y de su hijo. 